\title{
Recessively inherited growth hormone deficiency in a family from Iraq
}

\author{
MALCOLM D C DONALDSON, SAM M TUCKER, AND DAVID B GRANT
}

From the Department of Endocrinology, The Hospital for Sick Children, Great Ormond Street, London WCIN 3JH, and the Department of Paediatrics, Hillingdon Hospital, Uxbridge, Middlesex UB8 $3 N N$

SUMMARY A family from Iraq with five growth hormone deficient children in two closely related sibships is reported. The clinical forms and modes of inheritance of familial growth hormone deficiency are discussed briefly.

The inherited forms of growth hormone deficiency appear to be relatively uncommon, ${ }^{1}$ but it is well known that in a proportion of cases the condition is inherited as a recessive disorder, either as an isolated deficiency, ${ }^{2-6}$ or as a multiple deficiency of anterior pituitary hormones. ${ }^{7-9}$ Most of the families reported have been from the United States, ${ }^{2} 31011$ but examples from Europe, ${ }^{14}$ Israel, $^{5}$ and Japan $^{6}$ have been described. Some of the most striking examples have been found in closed communities with high consanguinity rates. We report a further family from Iraq with five growth hormone deficient children in two closely related sibships.

\section{Case reports}

The five children, three boys and twin girls aged from 2.9 to 7.7 years, were referred for investi-

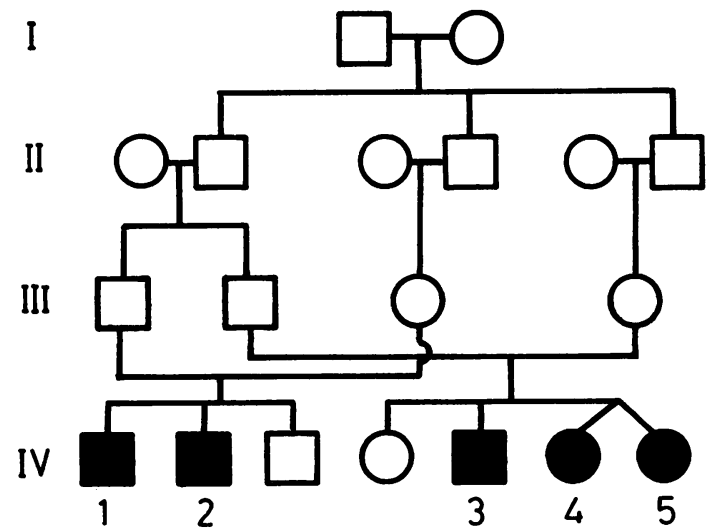

FIG 1 Pedigree of the five children with growth hormone deficiency.

Received for publication 18 December 1979 gation of severe growth failure. As shown in fig $1, \infty$ the two fathers are brothers who are married to $\frac{}{7}$ first cousins. In each sibship there is one child of $\vec{\nabla}$ normal size. All four parents are of normal height and there are no other cases of abnormal short $\frac{c}{\omega}$ stature known in the family.

All five children appeared normal at birth but $\vec{\emptyset}$ delayed growth became evident in early infancy. In. other respects their health was normal and their $\square$ parents considered them to be of normal intelligence.

The patients' clinical details are summarised in $\bar{\partial}$ table 1 and their appearance is shown in fig 2. They were all extremely small (height $-6 \cdot 6$ to $-9 \cdot 0 \mathrm{SD}$ ) and showed mid-face hypoplasia with apparently $\underset{\vec{F}}{\overrightarrow{2}}$ prominent eyes and prominent foreheads with normal cranial vaults. Ample subcutaneous fat was

TABLE 1 Clinical and laboratory data in the patients

\begin{tabular}{|c|c|c|c|c|c|}
\hline & $I V .1$ & IV.2 & $I V .3$ & $I V .4$ & $I V .5$ \\
\hline \multicolumn{6}{|l|}{ Clinical data } \\
\hline Sex & $\mathbf{M}$ & & M & $\mathbf{F}$ & $\mathbf{F}$ \\
\hline Age (yr) & $7 \cdot 7$ & $6 \cdot 4$ & $5 \cdot 2$ & $2 \cdot 9$ & $2 \cdot 9$ \\
\hline $\begin{array}{l}\text { Height (cm) } \\
\text { (SD) }\end{array}$ & $\begin{array}{l}74 \\
(-9)\end{array}$ & $\begin{array}{l}74 \\
(-8 \cdot 2)\end{array}$ & $\begin{array}{l}79 \\
(-6 \cdot 6)\end{array}$ & $\begin{array}{l}66 \\
(-7 \cdot 4)\end{array}$ & $\begin{array}{l}63 \cdot 5 \\
(-7 \cdot 8)\end{array}$ \\
\hline $\begin{array}{l}\text { Weight (kg) } \\
\text { (SD) }\end{array}$ & $\begin{array}{l}11 \\
(-4 \cdot 2)\end{array}$ & $\begin{array}{l}10 \\
(-4 \cdot 6)\end{array}$ & $\begin{array}{l}10 \\
(-4 \cdot 3)\end{array}$ & 8 & $\begin{array}{l}7 \\
(-4 \cdot 9)\end{array}$ \\
\hline \multicolumn{6}{|l|}{ Head circum- } \\
\hline $\begin{array}{l}\text { ference (cm) } \\
\text { (SD) }\end{array}$ & $\begin{array}{l}46 \\
(-4 \cdot 6)\end{array}$ & $\begin{array}{l}48 \\
(-3 \cdot 0)\end{array}$ & $\begin{array}{l}48 \cdot 5 \\
(-2 \cdot 4)\end{array}$ & $\begin{array}{l}45 \cdot 0 \\
(-3 \cdot 2)\end{array}$ & $\begin{array}{l}44 \cdot 5 \\
(-3 \cdot 6)\end{array}$ \\
\hline \multicolumn{6}{|c|}{ Laboratory data (after overnight fast) } \\
\hline $\begin{array}{l}\text { Blood glucose } \\
(\mathrm{mmol} / \mathrm{l})\end{array}$ & $2 \cdot 5$ & $2 \cdot 3$ & $1 \cdot 2$ & 0.6 & $1 \cdot 8$ \\
\hline \multicolumn{6}{|l|}{ Growth } \\
\hline $\begin{array}{l}\text { hormone } \\
\text { (mU/1) }\end{array}$ & $<1 \cdot 0$ & $<1 \cdot 0$ & $<1 \cdot 0$ & $1 \cdot 2$ & $1 \cdot 1$ \\
\hline $\begin{array}{l}\text { Prolactin } \\
(\mathrm{mU} / 1)\end{array}$ & 308 & 804 & 863 & 996 & 242 \\
\hline $\begin{array}{l}\text { Thyroxine } \\
\text { (nmol/1) }\end{array}$ & 71 & 72 & 87 & 109 & 71 \\
\hline $\begin{array}{l}\text { Plasma cortisol } \\
(\mathrm{nmol} / \mathrm{l})\end{array}$ & 399 & 292 & 285 & 600 & 120 \\
\hline Bone age (yr) & $2 \cdot 7$ & $2 \cdot 0-2 \cdot 7$ & $2 \cdot 0$ & $1 \cdot 5$ & $1 \cdot 25-1 \cdot 5$ \\
\hline
\end{tabular}




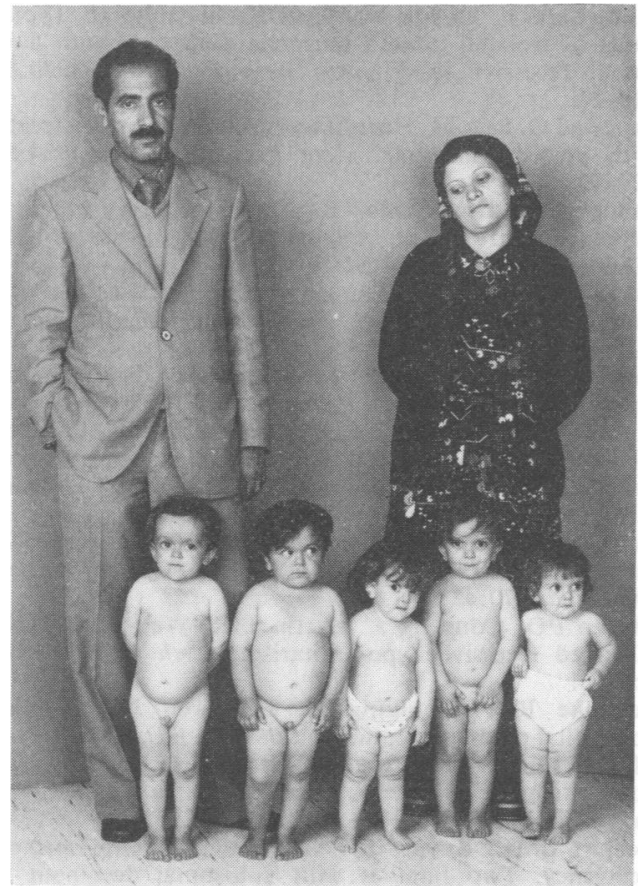

FIG 2 Appearance of the children with inherited growth hormone deficiency, together with one parent from each family.

present (weight $-4 \cdot 2$ to $-4 \cdot 9$ SD), and in the three boys the penises appeared relatively small although the testes were normally descended.

\section{INVESTIGATIONS}

The results of the laboratory investigations are summarised in table 2. Bone age was markedly retarded in all the patients. Their pituitary fossae appeared rather small on lateral skull radiographs.

TABLE 2 Growth hormone and cortisol values after glucagon stimulation in IV.1 and IV.3

\begin{tabular}{llll}
\hline & $\begin{array}{l}\text { Glucose } \\
(\text { mmol } / l)\end{array}$ & $\begin{array}{l}\text { Growth hormone } \\
(\mathrm{mU} / l)\end{array}$ & $\begin{array}{l}\text { Cortisol } \\
(\mathrm{nmol} / \mathrm{l})\end{array}$ \\
\hline$I V .1$ & & & \\
$0^{\prime}$ & 2.5 & $<1.0$ & - \\
$60^{\prime}$ & 7.3 & $<1.0$ & - \\
$90^{\prime}$ & 7.0 & $<1.0$ & 816 \\
$120^{\prime}$ & 3.6 & $<1.0$ & 480 \\
$150^{\prime}$ & 2.1 & & \\
$I V .3$ & & $<1.0$ & 285 \\
$0^{\prime}$ & 1.2 & $<1.0$ & - \\
$60^{\prime}$ & 2.5 & $<1.0$ & 700 \\
$90^{\prime}$ & 1.3 & 2.1 & 895 \\
$120^{\prime *}$ & 0.7 & 1.0 & \\
\hline
\end{tabular}

*Test terminated owing to severe symptomatic hypoglycaemia.
All five children showed asymptomatic hypoglycaemia after an overnight fast (blood glucose 0.6 to $2.5 \mathrm{mmol} / \mathrm{l}$ ), and basal growth hormone levels estimated by radioimmunoassay ${ }^{12}$ were below $1.5 \mathrm{mU} / \mathrm{l}$. Plasma thyroxine was in the low-normal range (71 to $109 \mathrm{nmol} / \mathrm{l})$, as was basal plasma cortisol (128 to $600 \mathrm{nmol} / \mathrm{l})$. Serum prolactin was raised to between 804 and $996 \mathrm{mU} / 1$ in three of the children.

Glucagon stimulation tests were carried out in the oldest child from each family (IV.1 IV.3), as shown in table 2. After injection of $100 \mu \mathrm{g} / \mathrm{kg}$ glucagon there was no appreciable rise in plasma growth hormone in either child, but the plasma cortisol levels rose from 400 to $816 \mathrm{nmol} / \mathrm{l}$ in IV.1 and from 285 to $895 \mathrm{nmol} / 1$ in IV.3. In IV.1 blood glucose rose from $2 \cdot 5$ to $7 \cdot 3 \mathrm{mmol} / \mathrm{l}$ at 60 minutes and then fell to $2 \cdot 1 \mathrm{mmol} / 1$ at 105 minutes. There was a small rise in blood glucose from 1.2 to $2.5 \mathrm{mmol} / 1$ in IV.3, and severe symptomatic hypoglycaemia developed after 120 minutes (blood glucose $0 \cdot 7$ $\mathrm{mmol} / \mathrm{l})$.

\section{Discussion}

Like most of the reported families with inherited growth hormone deficiency, the present inbred family shows the typical pattern of a recessive disorder, and it is interesting that the facial appearance of our cases, with mid-face hypoplasia, is similar to that described in other families. ${ }^{6} 11$

It is evident that growth hormone deficiency is a heterogeneous condition, both from the various modes of inheritance and from the different clinical forms observed in reported cases. While recessive inheritance is the most common pattern in affected families, $\mathrm{X}$ linked inheritance has been described, ${ }^{\mathbf{1 3}} 14$ as has autosomal dominant inheritance. ${ }^{1516}$

In some families growth hormone deficiency seems to be an isolated defect and secondary sexual development is normal, although often delayed. In others there is a more widespread loss of anterior pituitary function, with varying combinations of hormone deficiency which, according to Rimoin, ${ }^{17}$ will always include the gonadotrophins. Rarely, growth hormone deficiency is inherited in association with another syndrome..$^{18} 19$

The size of the pituitary fossa also varies in different families. In some it is normal, while in others it may be small or enlarged. ${ }^{9}$ The two sisters described by Ferrier and Stone ${ }^{10}$ were each found to have a very small sella turcica in an abnormal sphenoid bone. In our cases the pituitary fossae appeared rather small on lateral skull radiographs but, as $\mathrm{Di}$ Chiro and Nelson ${ }^{20}$ have pointed out, 
this view alone is unreliable in estimating the volume of the fossa.

As only two of our cases were challenged with glucagon we do not have detailed results of pituitary function in all our patients. However, the normal basal values for cortisol and the increments obtained after glucagon in two patients indicate that there was no disturbance of pituitary-adrenal function. Similarly, the low-normal plasma thyroxine values suggest that TSH secretion was also normal. The raised basal plasma prolactin levels found in three patients are difficult to interpret but could possibly be related to stress.

Perhaps the most striking feature of our cases was their fasting hypoglycaemia which was not the result of secondary adrenal insufficiency. Although symptomatic hypoglycaemia in isolated growth hormone deficiency (as opposed to hypopituitary states) has been described, ${ }^{16} 21$ it is not a constant feature of this condition, being absent in all 24 cases described by Rimoin et al. ${ }^{11}$ This inconsistency, together with the discovery of two different types of insulin response to arginine infusion in the latter series of patients, illustrates further the considerable heterogeneity that exists among cases of familial growth hormone deficiency.

We thank Dr P B S Fowler for referring the patients.

\section{References}

1 Rona RJ, Tanner JM. Aetiology of growth hormone deficiency in England and Wales. Arch Dis Child 1977; 52:197-208.

2 McKusick VA, Rimoin DL. General Tom Thumb and other midgets. Sci Am 1967;217:102-10.

3 Rimoin DL, Merimee TJ, McKusick VA. Growth hormone deficiency in man: an isolated, recessively inherited defect. Science 1966;152:1635-46.

4 Seip M, Van der Hagen CB, Trygstad O. Hereditary pituitary dwarfism with spontaneous puberty. Arch Dis Child 1968;43:47-52.

5 Pertzelan A, Adam A, Laron Z. Genetic aspects of pituitary dwarfism due to absence or biological inactivity of growth hormone. Isr J Med Sci 1968 ;4:895-900.
- Kumahara Y, Okuda Y, Miyai K, Inatsubo H. Typical cases of isolated growth hormone deficiency with auto- $\stackrel{\mathbb{P}}{\longrightarrow}$ somal recessive inheritance. Acta Endocrinol 1970;63: 618-24.

7 Trygstad O, Seip M. Hereditary pituitary dwarfism treated with growth hormone. Acta Paediatr Scand 1964;53: 527-32.

8 Sadeghi-Nejad A, Senior B. Absent pituitary gland. A familial syndrome of isolated aplasia of the antericr $\mathbb{D}$ pituitary. J Pediatr 1974;84:79-84.

- Parks JS, Tenore A, Bongiovanni AM, Kirkland RT. ڤ Familial hypopituitarism with a large sella turcica. $N \rightarrow$ Engl J Med 1978;298:698-702.

10 Ferrier PE, Stone EF. Familial pituitary dwarfism with an abnormal sella turcica. Pediatrics 1969;43:858-65.

11 Rimoin DL, Merimee TJ, Rabinowitz D, Cavilli-Sforza LL, McKusick VA. Genetic aspects of growth hormone deficiency. In: Pecile A, Muller EE, eds. Growth hormone. Amsterdam: Excerpta Medica, 1968:418-32.

12 Grant DB, Jackson D, Raiti S, Clayton BE. Serum growth is hormone levels after Bovril and insulin stimulation. Arch iv Dis Child 1970;45:544-6.

13 Phelan PD, Connelly J, Martin FIR, Wettenhall HNB. X-linked recessive hypopituitarism. Birth Defects 1971; 근 7:21-3.

14 Schimke RN, Spaulding JJ, Hollowell JG. X-linked congenital panhypopituitarism. Birth Defects 1971 ; 7:21-3.

15 Sheikholislam BM, Stempfel RS. Hereditary isolated $\frac{C}{\mathscr{A}}$ somatotrophin deficiency: effects of human growth hor- $\stackrel{9}{+}$ mone administration. Pediatrics 1972;49:362-74.

16 Poskitt EME, Rayner PHW. Isolated growth hormone deficiency. Two families with autosomal dominant in- ? heritance. Arch Dis Child 1974;49:55-9.

17 Rimoin DL. Hereditary forms of growth hormone deficiency and resistance. Birth Defects 1976;12:15-29.

18 Zachmann M, Illig R, Prader A. Fanconi's anaemia with $\bar{\partial}$ isolated growth hormone deficiency. J Pediatr 1972;80: $159-60$.

19 Sadeghi-Nejad A, Senior B. Autosomal dominant transmission of isolated growth hormone deficiency in iris- $\overrightarrow{\bar{O}}$ dental dysplasia (Rieger's syndrome). $J$ Pediatr 1974;85: 3 644-8.

20 Di Chiro G, Nelson KB. The volume of the sella turcica. AJR 1962;87:989-1008.

21 Wilber JF, Odell WD. Hypoglycaemia and dwarfism associated with the isolated deficiency of growth hormone. Metabolism 1965;14:590-7.

Requests for reprints to Dr D B Grant, Department of Endocrinology, The Hospital for Sick Children, Great Ormond Street, London WC1N 3JH. 